\begin{tabular}{|c|c|}
\hline & Volume \& Issues Obtainable at The Women University Multan \\
Annals of Social Sciences and Perspective \\
ISSN: 2707-7063, Volume 2, No.2 December 2021
\end{tabular}

\title{
Stock Return Predictability and Market Efficiency in Pakistan; A Role of Asian Growing Economies of India and Malaysia
}

\author{
Syed Usman Qadri ${ }^{1}$, Naveed Iqbal ${ }^{2}$, Syeda Shamaila Zareen ${ }^{3}$ \\ ${ }^{1}$ Assistant Professor, Department of Management Science, Times Institute, Multan \\ ${ }^{2}$ Capital University of Science and Technology, Islamabad, Pakistan \\ ${ }^{3}$ PhD Scholar, Beijing University of Technology

\section{ARTICLE DETAILS} \\ History: \\ Received: \\ Review: \\ Accepted: \\ Available Online:November 24, 2021

\section{Keywords:} \\ Stock Market Returns Predictability, \\ Stock Market crash, Market \\ efficiency

\section{DOI:} \\ 10.52700/assap.v2i2.95

\section{ABSTRACT} \\ The purpose of this study is to determine the \\ predictability of the Pakistani stock market's one-day \\ October 21, 2021 forward returns by utilizing lagged daily returns for \\ November 01,2021 Pakistan, India, and Malaysia from 2006 to 2016. The \\ findings indicate that lagged Pakistani market returns \\ significantly predict Pakistani one-day market returns. \\ However, the other two growing stock markets, India \\ and Malaysia, show no association with one-day ahead \\ market returns. Mostly, stock market behavior in the \\ pre-2008 and post-2008 eras was the same, although \\ industry return behavior was different due to the \\ economic crisis of 2008. However, the Pakistani stock \\ market one-day ahead returns predict the own Pakistani \\ lag returns due to an inefficient market and prices do not \\ follow a random walk. As a result, investors and \\ financial analysts can foresee and generate anomalous \\ returns by using previous data and information. \\ (C) 2021 The Authors, Published by WUM. This is an Open Access Article \\ under the Creative Common Attribution Non Commercial 4.0
}

Corresponding author's email address: usmangillani79@yahoo.com

\section{Introduction}

Humans have long wished to know what would happen in the future. Investors and analysts have not escaped this need; in addition to their other inquiries, they must also deal with the following questions: Are stock and financial market predictable? Is there any opportunity exists to attain abnormal earnings knowing given market dynamics and knowing nature and bases of movements in the stock market. Since 1980, researchers and financial authorities have predicted that asset prices will always follow a random walk. It was also believed that investors cannot outperform the market in any security by predicting the future return. It was supposed that a stock price reflects all information. Fama (1970) presented the efficient market hypothesis (EMH). The efficient market hypothesis (EMH) does not admit the presence of forecasting. The efficiency of all three distributions is based on the information. 
The information is categorized into historical, public, and private concerning information efficiency of the market (weak, semi, and strong form). This form of information market efficiency is also called predictability, event study, and private information (Fama, 1991). Almost 30 years later, Campbell et al (1997), explore that practically a random walk hypothesis is not followed by stock prices and stock are predictable at a certain level. Over time, the prediction of returns has been found by several researchers and studies. Different studies ascribe it to market inefficiency, whereas others assume that there would be different expected returns. Debondt and Thaler (1985) stated that the investor may overreact to the opportunities of profitable trading. This specifies that markets are not efficient or inefficient to a certain level. Though, predictability may also be indirect that markets are not efficient. Charles m. Jones and Gautam Kaul (1996) stated that the changes in time-varying risk premium may contribute to market predictability. Ferson et al. $(1991,1994)$ examined that global macro-economic variable have predictive power in several economies. Empirical asset pricing is the most uncertain issue of all investment-related matters. The development of the revolution in capital markets in Latin America, Europe, Asia, Africa, and the Middle East has created investors with new speculation opportunities, where low correlation amid developing marketplaces and developed economies give increase to diversification benefits. These opportunities with higher expected returns have generated global investors' attention. Investors are concerned about the prospect of reducing portfolio risk while maintaining expected returns.

M. Hashem Pesaran and Allan Timmermann's (1995) study shows that economic aspects used for estimation can vary over time. It has been found that returns predictability differs from the instability of returns. In low volatile marketplaces, the equity looked to have little predictability and vice versa in high volatile marketplaces. It was also argued that equity returns predictability does not merely rely on the business cycle, but is also affected by various market shocks. Therefore, this shows that stock returns might be higher predictable in established markets compared to emerging economies. Kim, Shamsuddin and Lim (2009) investigated the stock market return predictability in the US. They found that market returns are not predictable after the market crash and the behavior of the stock market was also the same after the crash. Gabriel Hawawini and Donald B. Keim (1995) determined that developing economies have greater explanatory power and greater prediction returns than advanced markets. Emergent economies show higher mean reversion as compared to established markets, with an upper grade of autocorrelation. These all with the developing standing of developing markets and their growing economic movement stimulate a pragmatic investigation of conceivable stock return predictability in these economies. Thus, this research objects to explore the main three developing stock markets in Asia namely Pakistan, India, and Malaysia. The mainstream of studies on stock returns predictability emphasizes advanced markets. This studies key focused to discuss the predictability regarding Asian markets to forecast future returns. Keeping this in mind, testing the market efficiency and stock return predictability is highly significant as it reflects the true image of the economy and the real sense of market sustainability. Hence, this study is important because it provides insights for investors. It can be said that investors, financial managers, and technical analysts may use this information and findings to predict more accurately and precisely. The study has the following research questions;

1. Does Pakistani one-day-ahead return predicted by the Pakistani lagged market return?

2. Does Pakistani one-day-ahead return predicted by the India lag market return? 


\section{Does Pakistani one-day-ahead return predicted by Malaysia's lagged market return?}

4. Is there any change in the behavior of the stock market when the stock market crash?

\section{Literature Review}

The purpose of this study is to determine the predictability of returns in Asian markets using market and industry returns. Past researchers have focused on the different internal domestic variables and also global macro variables to check the stock market returns predictability. The variables are company valuation level; Book-to-Market ratio, Price-to-Earnings ratio, Price- Dividend ratio, etc., Macro level; Exchange Rate (trade weighted index), inflation, Interest Rate, Output-Gap, etc., Technical level; Six and Twelve months Momentum Mean Reversion, etc., Comprehensive level; Baltic Dry Index and US Variance Risk Premium, etc. Experimental studies classically follow one out of two tactics. The main approach is to inspect stock predictability by a cross sectional analysis, which clarifies the connection among fundamental variables. (earnings yield, book-to-market, Dividend yield, etc). The studies, Fama \& French (1992) and Lakonishok (1994), use this method. Another approach used is the time series to observe stock return predictability. This method has been used by: Chen et al. (1986) and Fama and French (1993). Fama and French (1988) and James M. Poterba and Lawrence H. Summers (1988) investigated the long term horizon predictability and find some mean version over returns over a long horizon (more than two years). Masih and Masih (1997, 1999), study in the developed stock market and find that other developed markets such as the UK, US Germany, and Japan can impact other countries' stock markets such as South Korea, Singapore, Hong Kong, and Taiwan. Mostly, the stock index or returns of the portfolio may tend to be positively autocorrelated with many countries. Li et al. (2021) concluded that average correlation is an effective predictor in the majority of marketplaces. Technical analysis is part of the predicate of historical return Hawanini and Keim (1995) investigate the day effect and the use of different lagged economic and financial variables to predict the predictability of stock returns. They discover that Monday is a bad day for stock returns, while Friday is a relatively good day, and that dividend yield and interest are used to predict stock returns. Pesaran and Timmerman (1995) demonstrate that several variables such as dividend yield, price earnings ratio, interest rate, long term bond, and inflation all significantly predict stock returns. Lo et. al. (2000) established that, to a certain extent, the technical analysis might be beneficial in generating abnormal returns after correcting transaction costs. Alexakis, Patra, and Poshakwale (2010) evaluated the predictability of Athens stock returns from 1993 to 2006 using accounting data and panel data analytic techniques. The empirical evidence indicates that portfolio returns are greater than the average return. According to the studies, accounting information is not adequately integrated into the Greek emerging market, which is detrimental to market efficiency (EMH).

Guangjie Li (2011) examined how predicting stock returns using an uncertainty model can affect an investor's rational decision-making in the UK stock market from 1978 to 2003. The study discovered that stock return forecasting is less reliable, which can alter an investor's optimal portfolio choice over a variety of investment horizons. Louhichi (2012) analyzed the relationship between trading activity and stock returns during the time of period from 1965 to 2010. The measures of two different trading activities between raw volumes metric (Directional volume and no directional volume). The research concluded a positive relationship between the directional volume and stock returns. Direction volume helps to predict the stock returns. Goodness C. Aye (2014) investigated the stock returns predicted 
with daily stock market returns in Brazil, Russia, India, China and South Africa (BRICS) countries throughout 1995 to 2012 using an autoregressive fractionally integrated moving average model. They suggested that the autoregressive fractionally integrated moving average model performs better than the non-autoregressive fractionally integrated moving average model at forecasting the stock return. Mills (2006) also examined and forecasted UK stock returns from 1965 to 1990.

Ainul Islam and Mohammed Khaled (2005) conduct a statistical investigation of the Dhaka stock exchange's weak form of efficiency by utilizing daily and monthly data. Groenewold (1997) examined both weak and semi-strong forms of the EMH in New Zealand and Australia. These results show that weak and semi strong EMH hypotheses are rejected in both countries. Muhammad Akbar and Humayun Habib Baig (2010) examine the Pakistani stock market's inefficiency. They conclude that Pakistan's stock market remains inefficient. Investors are predicting stock prices from past historical data. Menzly and Ozbas (2010) investigate the predictability of stock market returns across markets. They discovered that when the number of educated investors increases, the predictability of returns across markets decreases. Dash, Sabharwal, and Dutta (2011) investigated the relationship between the month-of-the-year effect and market crisis effects on monthly returns in Indian equity markets.

The findings of this study demonstrate a month-of-the-year effect in Indian stock markets, with a positive influence in November, August, and December and a negative effect in March. Wen, Lin, Li, and Raco (2015) investigated the South African stock market and discovered a remarkable change when dividing the sample into pre and post periods and examining the impact on the stock exchange rate. The study results showed that the stock Exchange rate significantly affects on the stock exchange. Mustafa and Nishat (2007) evaluated the Pakistani stock market's efficiency and tested the random walk hypothesis. Daily, weekly, and monthly dates from December 1991 to May 2003 were used to divide the time period into three distinct sub periods. The results indicate that the random walk of the stock market is rejected for all three sub-periods in Pakistan, concluding that the stock market is inefficient. The study's hypothesis is as follows:

H1: Pakistani one-day-ahead returns are significantly predicted by the Pakistani lagged

market return.

H2: Pakistani one-day-ahead returns are significantly predicted by the India lagged market return.

H3: Pakistani one-day-ahead returns are significantly predicted by the Malaysia lagged market return.

H4: There is a significant relationship between market returns and the stock market crash.

\section{Data and Model Specification}

The sample is divided into two parts. In the first part, the daily closing prices for market indices are obtained to calculate the market returns regarding three developing countries of Asia, namely: Pakistan, India, and Malaysia. The sample period is of 11 years from January 2006 to December 2016. Data on closing prices are sourced from Yahoo Finance and the respective stock exchanges of selected countries, Pakistan stock Exchange (PSX), 
Kualalumpur stock exchange (KLSE) and Bombay Stock Exchange (BSE). In the second part, five portfolios are constructed based on five companies in each portfolio to find the industry returns for three developing countries. The industry returns are calculated through the natural algorithm of average prices for each portfolio. Similar to market returns the time frame for industry returns is also containing 11 years from 2006 to 2016. OLS regression estimation technique is employed for the analysis of data. All companies are selected based on market capitalization. The study has the following equations for analysis;

$R_{P K, t+1}^{M}=\beta_{0}+\beta_{1}+\beta_{3} R_{o t h e r, t}^{M}+\varepsilon_{t+1} \ldots$ (1)

$R_{P K, t+1}^{M,}=\beta_{0}+\beta_{1} R_{P K, t}^{M}+\beta_{2} R_{o t h e r, t}^{M}+\beta_{3} R_{P K, t}^{M} * D u m m y+\beta_{4} R_{o t h e r, t *}^{M} D^{M} m_{t}+\varepsilon_{t+1} . .(2)$

The first econometric model of this study includes the following variables.

Where, $\mathrm{R}_{\mathrm{PK}, \mathrm{t}+1}^{\mathrm{M}}$ is the dependent variable and defined as the one-day ahead market returns of Pakistan. Whereas, the independent variables are lagged Pakistani returns Pakistan $\left(\mathrm{R}_{\mathrm{kse}, \mathrm{t}}^{\mathrm{M}}\right)$ and lagged $\mathrm{R}_{\mathrm{other}, \mathrm{t}}^{\mathrm{M}}$ returns on other stock markets including, the India $\left(\mathrm{R}_{\mathrm{Bse}, \mathrm{t}}^{\mathrm{M}}\right)$, and Malaysia $\left(\mathrm{R}_{\mathrm{klst}}^{\mathrm{M}}\right)$, Daily $\mathrm{t}$, and $\varepsilon_{\mathrm{t}+1}$ is an error term.

The second econometric model of this study includes the following variables.

Where, $\mathrm{R}_{\mathrm{PK}, \mathrm{t}+1}^{\mathrm{M}}$ is the dependent variable and defined as the one-day ahead market return in Pakistan. While the independent variables are $R_{P K, t}^{M}$ (return of $\mathrm{PK}$ ) $\mathrm{R}_{\mathrm{other}, \mathrm{\textrm {T }}}^{\mathrm{M}}$ are returns on other stock markets including Pakistan, India, and Malaysia. The study also includes a dummy $\left(\right.$ Dum $\left._{t}\right)$ variable to check the stock market in 2008 due to the stock market crash. The coefficient of the interaction term $\left(\mathrm{kR}_{\mathrm{other}, \mathrm{t}}^{\mathrm{M}} \mathrm{Dum} \mathrm{t}\right)$ captures the change in the effect of other markets on the Pakistan market in the post-2008 period, compared to the earlier period and $\varepsilon_{t+1}$ the error term.

\subsection{Descriptive Statistics}

Descriptive statistics provide a useful summary of information when performing empirical analysis as they provide a historical account for all series behavior. Descriptive statistics of all variables during the period of study is 2006 to 2016 are as follows:

Table 1: Descriptive Statistics

\begin{tabular}{lllll}
\hline & PSX T(t+1) & PSX & BSE & KLS \\
\hline Mean & 0.000839 & 0.000841 & 0.000613 & 0.000382 \\
\hline Median & 0.001112 & 0.001134 & 0.001046 & 0.000529 \\
\hline Maximum & 0.020831 & 0.020831 & 0.022936 & 0.011836 \\
\hline Minimum & -0.023438 & -0.023438 & -0.023693 & -0.011461 \\
\hline Std. Dev. & 0.010598 & 0.010599 & 0.011986 & 0.005783 \\
\hline Skewness & -0.343950 & -0.344487 & -0.148888 & -0.081423 \\
\hline Kurtosis & 3.087681 & 3.087470 & 2.585047 & 2.721173 \\
\hline Jarque-Bera & 54.20067 & 54.36342 & 29.40070 & 11.75138 \\
\hline Probability & 0.000000 & 0.000000 & 0.000000 & 0.002807 \\
\hline
\end{tabular}

Table 1 shows that the mean value of Pakistan one day ahead PSX $(t+1)$ is 0.0008 and its standard deviation is 0.010 . The maximum level of PSX T $(\mathrm{t}+1)$ during the observed period is 0.02 and its minimum level is -0.02 . The skewness value is negative which means the negative skewness of the data. The average value of Pakistan lagged term PSX (t) is 0.0008 and its standard deviation is 0.010 . The maximum level of PSX $(\mathrm{t})$ during the observed period is 0.02 and its minimum level is -0.2 . The mean value of India's lagged BSE ( $t$ ) is 0.0006 and its standard deviation is 0.011 . 
Table 2: Correlation Analysis

\begin{tabular}{lllll} 
& PSX $(\mathbf{t}+\mathbf{1})$ & PSX & BSE & KLS \\
\hline PSX $(\mathrm{t}+1)$ & 1.000000 & & & \\
\hline PSX & 0.140047 & 1.000000 & & \\
\hline BSE & -0.002862 & -0.001247 & 1.000000 & \\
KLS & -0.019933 & 0.046241 & 0.011147 & 1.000000 \\
\hline
\end{tabular}

Table 2 shows the results of the correlation analysis. Variables are positively and negatively correlated with each other. The PSX value (0.14) indicates a positive relationship between Pakistan lagging and one day ahead of Pakistani returns. The BSE value (-0.002) indicates the negative correlation of BSE and one day ahead of Pakistani returns. Meanwhile, the value $(-0.00124)$ confirms the negative correlation between BSE and PSX.

The KLS (-0.01993) indicates a negative relationship between KLS and one day ahead Pakistan returns. However, the values respectively $(0.04624 \& 0.01114)$ are indicating the positive relationship between KLS with PSX and KLS with BSE lagged market returns.

Table 3: Simple Regression Analysis of Market

\begin{tabular}{lllll}
\hline Variable & Coefficient & Std. Error & t-Statistic & Prob. \\
\hline $\mathrm{C}$ & 0.000631 & 0.000253 & 2.494977 & 0.0127 \\
\hline Pakistan & 0.141263 & 0.019065 & 7.409599 & 0.0000 \\
\hline India & -0.002007 & 0.015988 & -0.125548 & 0.9001 \\
\hline Malaysia & -0.037371 & 0.026951 & -1.386632 & 0.1657 \\
\hline Adjusted R-squared & 0.019230 & & & \\
\hline F-statistic & 18.67225 & Durbin-Watson stat & 2.002017 \\
\hline Prob (F-statistic) & 0.000000 & & & \\
\hline
\end{tabular}

Table 3 shows that the results of returns predictability at the market (country) level. The study performed the full sample regression) analysis. The empirical results show that the lagged Pakistan return compared to other countries' returns, has great predictive power (significant at the level of 5\%). However, there is no evidence of predictability for Pakistan lagged market returns on India and Malaysia stock returns. But the Pakistani stock market lagged returns only predict the Pakistani stock market. The coefficient (14\%) of the Pakistan stock market indicates that the one percent increase in the Pakistan market returns will push up the PSX $t+1$ market return by $14 \%$ basis points in the next day. Though, the negative and significant means that redaction in the next day of the period. These results are consistent with the studies of Mustafa and Nishat (2007).

Table 4: Pre 2008 Crash Stock Market Regression Analysis

\begin{tabular}{lllll}
\hline Variable & Coefficient & Std. Error & t-Statistic & Prob. \\
\hline C & 0.000752 & 0.000204 & 3.688974 & 0.0002 \\
\hline PSX & 0.108650 & 0.028840 & 3.767315 & 0.0002 \\
\hline BSE & -0.025259 & 0.025049 & -1.008375 & 0.3134 \\
\hline
\end{tabular}




\begin{tabular}{|c|c|c|c|c|}
\hline KLS & -0.043868 & 0.052154 & -0.841138 & 0.4003 \\
\hline DUMMY PRE PSX & 0.017352 & 0.038461 & 0.451149 & 0.6519 \\
\hline$\underline{\text { DUMMY PRE BSE }}$ & 0.054331 & 0.033948 & 1.600412 & 0.1096 \\
\hline DUMMY PRE KLS & 0.032496 & 0.070448 & 0.461273 & 0.6446 \\
\hline Adjusted R-squared & 0.013100 & & & \\
\hline F-statistic & 6.982172 & \multicolumn{2}{|c|}{ Durbin-Watson stat } & 2.007956 \\
\hline Prob(F-statistic) & 0.000000 & & & \\
\hline
\end{tabular}

When including the Dummy variable in the regression model. The returns predictability for all developing stock markets is not statistically significant on pre period 2008 market crash. Table 4 the study also included dummy variables in the regression model to capture stock market behaviors before the stock market crash. The returns predictability of all developing stock markets is not statistically significant per period 2008. The Durbin-Watson value is 2.00 which means there is no autocorrelation problem and F-statistic value 6.98 and probability P-Value (0.00) is significant that's mean model is a good fit.

Table 5: Post 2008 Crash Stock Market Regression Analysis

\begin{tabular}{lclcc} 
Variable & Coefficient & Std. Error & t-Statistic & Prob. \\
\hline $\mathrm{C}$ & -9.900000 & 0.000216 & -0.457442 & 0.6474 \\
\hline KSE & 0.105306 & 0.025431 & 4.140807 & 0.0000 \\
\hline BSE & 0.025632 & 0.025082 & 1.021912 & 0.3069 \\
\hline KLS & -0.031256 & 0.049954 & -0.625687 & 0.5316 \\
\hline DUMMY POST KSE & 0.040544 & 0.039006 & 1.039422 & 0.2987 \\
\hline DUMMY POST BSE & -0.039820 & 0.035467 & -1.122731 & 0.2617 \\
\hline DUMMY POST KLS & -0.005969 & 0.075024 & -0.079558 & 0.9366 \\
\hline Adjusted R-squared & 0.014109 & & & \\
\hline F-statistic & 7.387269 & Durbin-Watson stat & 2.004512 \\
\hline Prob(F-statistic) & 0.000000 & & & \\
\hline
\end{tabular}

Table 5 used dummy variables in the regression model to capture stock market behaviors after the stock market crash. The returns predictability of all developing stock markets is not statistically significant in the post period 2008. The Durbin-Watson value is 2.00 which means there is no autocorrelation problem and F-statistic value 7.38 and, probability P-Value (0.00) is significant, that's mean model is a good fit. 
Table 6: Fama Macbeth's Method

\begin{tabular}{|c|c|c|c|c|c|}
\hline \multicolumn{6}{|c|}{ Panel one } \\
\hline & \multicolumn{5}{|c|}{$X_{t} \in\left\{\right.$ Spread $_{s}-$ Roll $_{t} ; G i b b_{s} ;$ Amihud $:$ Gamma $\}$} \\
\hline & Spread & Roll & $G i b b s$ & Amihud & Gamma \\
\hline $\begin{array}{l}\text { Coef. } \\
t \text {-stat. }\end{array}$ & $\begin{array}{l}0.082 \\
6.88\end{array}$ & $\begin{array}{l}0.039 \\
6.43\end{array}$ & $\begin{array}{l}0.053 \\
3.68\end{array}$ & $\begin{array}{l}-0.589 \\
-7.64\end{array}$ & $\begin{array}{l}0.004 \\
1.47\end{array}$ \\
\hline \multicolumn{6}{|c|}{ Panel Two } \\
\hline \multicolumn{6}{|c|}{$\underline{X}_{t}=\left\{\right.$ Spread $_{t}-$ Roll $_{t} ;$ Gibbs $_{s} ;$ Amihud $_{t} ;$ Gamm $\left._{2}\right\}$} \\
\hline & Spread & Roll & Gibbs & Amihud & Gamma \\
\hline $\begin{array}{l}\text { Coef. } \\
t \text {-stat. }\end{array}$ & $\begin{array}{l}0.047 \\
5.85\end{array}$ & $\begin{array}{l}0.009 \\
2.88 \\
\end{array}$ & $\begin{array}{l}0.064 \\
5.24\end{array}$ & $\begin{array}{l}-0.553 \\
-7.42\end{array}$ & $\begin{array}{l}-0.01 \\
-1.77 \\
\end{array}$ \\
\hline
\end{tabular}

Spread, Roll, and Gibbs measure effective bid-ask spread as a percentage of the stock price and are described in Corwin and Schultz (2012), Roll (1984), and Hasbrouck (2009). Amihud and Gamma measure price impact as described in Amihud (2002) and Pastor and Stambaugh (2003). The annual measures are lagged by one year, and the quarterly and monthly measures are lagged by one quarter. The first group the Gibbs measure (Hasbrouck 2009), the Roll (1984) measure and the estimate of effective spread from Corwin and Schultz (2012) — can be generally described as spread measures. The second group the Amihud (2002) measure and the Pastor and Stambaugh (2003) gamma are often considered measures of price impact.

\section{Discussion of Result}

Based on these results the hypothesis is verified. Out of the four hypotheses developed in the stock market, the $\mathrm{H} 1$ hypothesis is accepted while the other three are rejected. There are significantly Pakistani one-day-ahead returns that predict the lagged Pakistani market returns. The Pakistan stock market is not efficient and sustainable prices don't move a random walk. The findings show that the prices are not randomly walked and the rational investors' again abnormal returns and predict the returns behaviors.

Moreover, three hypotheses $\mathrm{H} 2, \mathrm{H} 3$, and $\mathrm{H} 4$ are rejected because of the insignificant relationship between Pakistan's one-day-ahead return and lagged India and Malaysia market returns. Market-related hypotheses $\mathrm{H} 1$ are the one only where lagged market returns are predicted and the hypotheses are accepted at 5\% level of significance and the reaming lagged developing countries India and Malaysia return are not predicted at five percent level. The hypothesis (H4) is rejected because the stock market behaviors pre and post are the same. The hypothesis (H4) included a dummy variable the interaction term for the change in stock market behavior before and after the stock market crash period. The pre-period is from 2006 to 2008 and post period is from 2009 to 2016 in our regression analysis. The hypothesis H4 is also rejected because the stock market behaviors pre and post are the same. There is an insignificant relationship between stock market behavior in the stock market crash. This result is consistent with many other studies (Groenewold, 1997; Muhammad Akbar and Humayun Habib Baig 2010; Menzly and Ozbas, 2010; and Dash et al. 2011).

\section{Conclusion}

This study explored the return predictability for the Pakistan stock market using lagged country returns of its own and two other developing markets, including; India, Malaysia from January 2006 through December 2016. To estimate the results of returns predictability at the 
market level, the research performs the full sample regression analysis for the period of 2006 to 2016. Further, this relationship is also observed by adding and dummy variable (interaction term) that captures the impact of the stock market crash on stock market behavior. The empirical results show that the one-day- ahead Pakistani stock market returns are better predicted by its own lagged returns as compared to other countries' lagged stock returns. These results are significant at the 5\% level. Further, when the analysis included the dummy variable in the regression model, the predictability of the returns for all developing stock markets are found statistically insignificant. This means that there is no impact of pre and post period 2008 market crash on return predictability. In Pakistan, lagged stock market returns predict due to asymmetric information and insider trading. In Asymmetric information, one party is more informed than the other party. Pakistani market is violating the basic assumptions of efficient market hypotheses due to information asymmetric. Inefficient market all information is equally available to all buyers and sellers but in the case of Pakistan, stockholders are unaware and insider traders used the information for personal benefit. Haroon and Shah (2013) concluded the weak form of efficiency in the Pakistani stock market. The result shows that the random walk hypothesis is rejected and the Pakistani stock market is not efficient. The Future study may also conduct to include the different macroeconomics and financial variable to predict the stock market and industry return for analysis.

\section{Acknowledgment}

This research is sponsored in part by an important project of the National Social Science Fund of China under the project title "Innovation research on national Governance, State audit system and anti-corruption system," (13AZD002), chair, in 2013.

\section{References}

Akbar, M., \& Baig, H. H. (2010). The reaction of Stock Prices to Dividend Announcements and Market Efficiency in Pakistan. Lahore Journal of Economics, 15(1).

Amihud, Y. (2002). Illiquidity and stock return: cross-section and time-series effects. Journal of financial markets, 5(1), 31-56.

Alexakis, C., Patra, T., \& Poshakwale, S. (2010). Predictability of stock returns using financial statement information: evidence on semi-strong efficiency of emerging Greek stock market. Applied Financial Economics, 20(16), 1321-1326.

Aye, G. C., Balcilar, M., Gupta, R., Kilimani, N., Nakumuryango, A., \& Redford, S. (2014). Predicting BRICS stock returns using ARFIMA models. Applied Financial Economics, 24(17), 1159-1166.

Bondt, W. F., \&Thaler, R. (1985). Does the stock market overreact?. The Journal of Finance, 40(3), 793-805.

Campbell, J. Y., Lo, A. W. C., \&MacKinlay, A. C. (1997). The econometrics of financial markets (Vol. 2, pp. 149-180). Princeton, NJ: Princeton University Press.

Chen, N. F., Roll, R., \& Ross, S. A. (1986).Economic forces and the stock market.Journal of business, 383-403.

Corwin, S. A., \& Schultz, P. (2012). A simple way to estimate bid-ask spreads from daily high and low prices. The Journal of Finance, 67(2), 719-760.

Dash, M., Sabharwal, M., \& Dutta, A. (2011). Seasonality and market crash in Indian stock markets. Available at SSRN 1785112.

Fama, E. F., \& French, K. R. (1988).Permanent and temporary components of stock prices.The Journal of Political Economy, 246-273. 
Fama, E. F. (1991). Efficient capital markets: II. The journal of finance, 46(5), 1575-1617.

Fama, E. F., \& French, K. R. (1992). The cross-section of expected stock returns. The Journal of Finance, 47(2), 427-465.

Fama, E. F., \& French, K. R. (1993).Common risk factors in the returns on stocks and bonds.Journal of financial economics, 33(1), 3-56.

Ferson, W. E., \& Harvey, C. R. (1991).Sources of predictability in portfolio returns.Financial Analysts Journal, 47(3), 49-56.

Ferson, W. E., \& Harvey, C. R. (1991).The variation of economic risk premiums. Journal of Political Economy, 385-415.

Ferson, W. E., \& Harvey, C. R. (1994).Sources of risk and expected returns in global equity markets.Journal of Banking \& Finance, 18(4), 775-803.

French, K. R., \& Poterba, J. M. (1991). Were Japanese stock prices too high?. Journal of Financial Economics, 29(2), 337-363.

Groenewold Fraser, N. P. (1997). Share prices and macroeconomic factors. Journal of Business Finance \& Accounting, 24(9-10), 1367-1383.

Haroon, M. A., \& Shah, N. (2013). Investigating Day-of-the-Week Effect in Stock Returns: Evidence from Karachi Stock Exchange-Pakistan. Pakistan Journal of Commerce \& Social Sciences, 7(2).

Hasbrouck, J. (2009). Trading costs and returns for US equities: Estimating effective costs from daily data. The Journal of Finance, 64(3), 1445-1477.

Hawawini, G., \&Keim, D. B. (1995). On the predictability of common stock returns: Worldwide evidence. Handbooks in operations research and management science, 9, 497544.

Islam, A., \& Khaled, M. (2005). Tests of weak-form efficiency of the Dhaka stock exchange. Journal of Business Finance \& Accounting, 32(7-8), 1613-1624.

Jones, C. M., \& Kaul, G. (1996).Oil and the stock markets. The Journal of Finance, 51(2), 463-491.

Kim, J. H., Shamsuddin, A., \& Lim, K. P. (2011). Stock return predictability and the adaptive markets hypothesis: Evidence from century-long US data. Journal of Empirical Finance, 18(5), 868-879

Lakonishok, J., Shleifer, A., \& Vishny, R. W. (1994).Contrarian investment, extrapolation, and risk.The journal of finance, 49(5), 1541-1578.

Li, G. (2011). The horizon effect of stock return predictability and model uncertainty on portfolio choice: UK evidence. Applied financial economics, 21(11), 771-787.

Li, X., Chen, X., Li, B., Singh, T., \& Shi, K. (2021). Predictability of stock market returns New evidence from developed and developing countries. Global Finance Journal, 100624.

Lo, A. W., Mamaysky, H., \& Wang, J. (2000). Foundations of technical analysis: computational algorithms, statistical inference, and empirical implementation. The journal of finance, 55(4), 1705-1765

Louhichi, W. (2012). Does trading activity contain information to predict stock returns? Evidence from Euronext Paris. Applied Financial Economics, 22(8), 625-632.

Fama, E. F. (2021). Efficient capital markets a review of theory and empirical work. The Fama Portfolio, 76-121.

Masih, A. M., \& Masih, R. (1997). Dynamic linkages and the propagation mechanism driving major international stock markets: An analysis of the pre-and post-crash eras. The Quarterly Review of Economics and Finance, 37(4), 859-885. 
Masih, A. M., \& Masih, R. (1999). Are Asian stock market fluctuations due mainly to intraregional contagion effects? Evidence based on Asian emerging stock markets. Pacific-Basin Finance Journal, 7(3), 251-282.

Menzly, L., \& Ozbas, O. (2010).Market Segmentation and Cross-predictability of Returns. The Journal of Finance, 65(4), 1555-1580.

Mill, G. A. (2006). The financial performance of a socially responsible investment over time and a possible link with corporate social responsibility. Journal of Business Ethics, 63(2), 131.

Mustafa, K., \& Nishat, M. (2007).Testing for market efficiency in emerging markets: a case study of the Karachi Stock Market. The Lahore Journal of Economics, 12(1), 119140.

Pástor, L', \& Stambaugh, R. F. (2003). Liquidity risk and expected stock returns. Journal of Political economy, 111(3), 642-685.

Pesaran, M. H., \& Timmermann, A. (1995). Predictability of stock returns: Robustness and economic significance. The Journal of Finance, 50(4), 1201-1228.

Poterba, J. M., \& Summers, L. H. (1988). Mean reversion in stock prices: Evidence and implications. Journal of financial economics, 22(1), 27-59.

Roll, R. (1984). A simple implicit measure of the effective bid-ask spread in an efficient market. The Journal of Finance, 39(4), 1127-1139.

Wen, Y. C., Lin, P. T., Li, B., \& Roca, E. (2015). Stock return predictability in South Africa: The role of major developed markets. Finance Research Letters, 15, 257-265. 